\title{
UWAGI NA TEMAT KSZTALTU PLANOWANEJ DYREKTYWY W SPRAWIE TRANSGRANICZNEGO PRZENIESIENIA SIEDZIBY SPÓŁKI
}

\section{WPROWADZENIE}

1. Europejskie prawo spółek (prawo spółek Unii Europejskiej) to zespół norm prawa unijnego gwarantujący spółkom korzystanie ze swobody przedsiębiorczości (art. $49 \mathrm{TfUE}^{1}$ ) oraz zapewniający funkcjonowanie rynku wewnętrznego przez harmonizację krajowego prawa spółek (art. 26 ust. 1 TfUE). W Planie działania $2012^{2}$ zostało zapowiedziane podjęcie przez Komisję różnego rodzaju inicjatyw, w tym wydanie unijnych przepisów mających spółkom ułatwić transgraniczna mobilność na wspólnym rynku. Wśród tych inicjatyw główna rola przypaść ma planowanej czternastej dyrektywie w sprawie transgranicznego przeniesienia siedziby spółki.

Przekonanie o potrzebie wydania czternastej dyrektywy jest niemal powszechne ${ }^{3}$. Trybunał nie może bowiem - wypełniając luki legislacyjne ustawodawcy unijnego ${ }^{4}$ - „tworzyć” unijnego prawa spółek bezpośrednio na mocy TfUE 5 . Sam Trybunał zreszta w wyroku z 12 lipca 2012 r. w sprawie C-378/10 (Vale) expressis verbis potwierdził, że unijne przepisy harmonizujące „są z pewnością przydatne [wyróż. - J.N.] dla ułatwienia przekształ-

1 Traktat o funkcjonowaniu Unii Europejskiej (Dz. Urz. UE C 115 z 9 maja 2008 r., s. 47).

${ }^{2}$ Komunikat Komisji z 12 grudnia 2012 r. do Parlamentu Europejskiego, Rady, Europejskiego Komitetu Ekonomiczno-Społecznego i Komitetu Regionów zatytułowany: „Plan działania. Europejskie prawo spółek i ład korporacyjny - nowoczesne ramy prawne na rzecz bardziej zaangażowanych udziałowców i zrównoważonych przedsiębiorstw”, COM (2012), 740. (Dalej jako: Plan działania 2012).

${ }^{3}$ „Free mobility for companies cross border has a long-standing dream for European businesses", W.-G. Ringe, Corporate Mobility in the European Union - A Flash in the Plan? An Empirical Study on the Success of Lawmaking and Regulatory Competition, „European Company and Financial Law Review" 2013, z. 2, s. 232.

${ }^{4}$ M.-P. Weller, B. Rentsch, Die Kombinationslehre beim grenzüberschreitenden Rechtsformwechsel - Neue Impulse durch Europarecht, „Praxis des Internationalen Privat- und Verfahrensrechts" 2013, z. 6, s. 531.

${ }^{5}$ K. J. Hopt, Europäisches Gesellschaftsrecht im Lichte des Aktionsplans der Europäischen Kommision vom Dezember 2012, „Zeitschrift für Unternehmens- und Gesellschaftsrecht” 2013, nr 2, s. 213; W. Schön, Das System gesellschaftrechtlichen Niederlassungsfreiheit nach VALE, „Zeitschrift für Unternehmens- und Gesellschaftsrecht” 2013, nr 3, s. 337. 
ceń transgranicznych" ". Teza ta koresponduje z zaleceniem $\mathrm{nr} 2$, stanowiacym załącznik do rezolucji Parlamentu Europejskiego z 2 lutego 2012 r. ${ }^{7}$ Także powołany z inicjatywy Dyrektora Generalnego do spraw Rynku Wewnętrznego i Usług zespół ekspertów (Grupa Refleksji) rekomenduje uchwalenie dyrektywy umożliwiającej spółkom przenoszenie siedziby do innego państwa członkowskiego z zachowaniem podmiotowości prawnej, a zarazem zabezpieczającej interesy wierzycieli, pracowników i wspólników ${ }^{8}$. Stworzenie możliwości transgranicznego przeniesienia siedziby poparła również większość uczestników konsultacji w sprawie przyszłości unijnego prawa spółek ${ }^{9}$.

Od Komisji UE oczekuje się przedłożenia konkretnego projektu. Natomiast Komisja UE - zgodnie z zapowiedzią w Planie działania $2012^{10}$ - przeprowadziła nową konsultację ${ }^{11}$ oraz opublikowała dokument podsumowujący ${ }^{12}$.

2. Plany Komisji dotyczą przenoszenia siedziby statutowej (ang. registered office, niem. Satzungsitz). W tle pojawiaja się jednak szczegółowe pytania dotyczące kształtu dyrektywy, w tym w szczególności dotyczace relacji między przeniesieniem siedziby statutowej a przeniesieniem siedziby faktycznej spółki. W wyroku w sprawie C-378/10 (Vale) Trybunał Sprawiedliwości UE (dalej: Trybunał lub TS) podkreślił bowiem - powołując się na wyrok z 12 września 2006 r. w sprawie C-196/04 (Cadbury Schweppes) - że istotnym elementem swobody przedsiębiorczości jest faktyczne wykonywanie działalności gospodarczej: „co się tyczy ograniczenia swobody przedsiębiorczości,

${ }^{6}$ Teza 38 zd. 2 wyrok TS z 12 lipca 2012 r. w sprawie C-378/10 (Vale). Wyroki TS dostępne na: http://curia.europa.eu.

7 Rezolucja Parlamentu Europejskiego zawierająca zalecenia dla Komisji w sprawie 14. dyrektywy o prawie spółek dotyczącej transgranicznego przeniesienia siedziby spółki (2011/2046/ (INI)). P7_TA(2012)0019. Por. także Rezolucja Parlamentu Europejskiego z 4 czerwca 2012 r. w sprawie przyszłości europejskiego prawa spółek (2012/2669(RSP). P7_TA(2012)0259.

${ }^{8}$ Report of the Reflection Group on the Future of UE Company Law z 5 kwietnia $2011 \mathrm{r}$. http://ec.europa.eu/internal_market/company/docs/modern/reflectiongroup_report_en.pdf. Grupa Refleksji uchwalenie dyrektywy traktuje jako sprawę priorytetową także w swej ocenie dotyczacej Planu działania 2012: Response to the European Commission's Action Plan on Company Law and Corporate Governance by the former Reflection Group on the Future of UE Company Law, „European Company and Financial Law Review" 2013, z. 3, s. 318-320.

${ }^{9}$ Za opowiedziało się 373 z 496 uczestników konsultacji - pkt 4.1 i przyp. 42 , s. 14 Planu działania 2012. Także Feedback Statement-Summary of Responses to the Public Consultation on the Future of European Company Law, July 2012, s. 4.

10 Zapowiedź ponownej konsultacji spotkała się z krytyką doktryny prawa W. Schön, op. cit., s. 337. P. Błaszczyk, Przyszłość europejskiego prawa spółek $i$ ładu korporacyjnego $w$ najnowszym Planie działania (Action Plan) Komisji Europejskiej, „Przegląd Prawa Handlowego” 2013, nr 4, s. 24. W. Bayer, J. Schmidt, BB-Gesetzgebung- und Rechtsprechungsreport Europäisches Unternehmensrecht 2012, Betriebs-Berater 2013, nr 1-2, s. 14. Krytykę podzieliła także Grupa Refleksji; Response to the European, s. 319-320, dodajac: „Consequently, we urge the European Commission to initiate legislation as a matter of priority".

11 Konsultacje w sprawie transgranicznego przenoszenia siedzib statutowych spółek prowadzone przez Dyrekcję Generalną ds. Rynku Wewnętrznego i Usług, http://ec.europa.eu/internal_ market/consultations/2013/seat-transfer/docs/consultation-document_pl.pdf.

12 Feedback Statement. Summary of responses to the public consultation on cross-border transfer of registered offices of companies, September 2013. 
należy przypomnieć, że pojęcie przedsiębiorczości w rozumieniu postanowień traktatu dotyczących swobody przedsiębiorczości zakłada faktyczne wykonywanie działalności gospodarczej przez stały zakład w przyjmującym państwie członkowskim przez czas nieokreślony. Zakłada ona zatem rzeczywiste utworzenie danej spółki w tym państwie i faktyczne wykonywanie w nim działalności gospodarczej” ${ }^{13}$. Trybunał dodał zarazem, że „w niniejszym przypadku nic w postępowaniu przed Trybunałem nie sugeruje, że Vale Építési będzie prowadzić działalność tylko na terytorium Włoch, zaś rzeczywistym celem tej spółki nie jest realne przeniesienie siedziby na Węry, choć ustalenie tej kwestii leży w gestii sądu odsyłającego" ${ }^{14}$. Ergo, jeżeli sąd węgierski stwierdzi, że spółka włoska nie zamierza prowadzić działalności gospodarczej na Węgrzech - a więc jej celem nie jest przeniesienie swej działalności gospodarczej do tego kraju - to nie może ona powoływać się na swobodę przedsiębiorczości (art. 49 i 54 TfUE).

Relacji między siedzibą statutową i faktyczną spółki dotyczyły również pytania postawione respondentom podczas przeprowadzonej konsultacji (w rozdziale V ankiety zatytułowanym: „Projekt instrumentu: - jak powinien wyglądać instrument UE dotyczący bezpośredniego przenoszenia siedzib statutowych spółek?): po pierwsze - czy przeniesienie siedziby statutowej powinno łączyć się z przeniesieniem siedziby faktycznej? ${ }^{15}$; po drugie - czy decyzja w tej kwestii powinna leżeć w gestii państw członkowskich? Na pierwsze (centralne) pytanie połowa respondentów, którzy udzielili na nie odpowiedzi, odpowiedziała pozytywnie ${ }^{16}$. Takie stanowisko podczas konsultacji zają również polski rząd ${ }^{17}$. Natomiast zdaniem Parlamentu Europejskiego wyrażonym w rezolucji z 2 lutego 2012 r. zakres czternastej dyrektywy „powinien obejmować odpowiednie rozwiązanie kwestii oddzielenia siedziby statutowej spółki od jej siedziby administracyjnej"18. Wariantu tego nie wyklucza Komisja UE skoro podczas konsultacji pyta o to, czy przeniesienie siedziby statutowej powinno łączyć się z przeniesieniem siedziby faktycznej.

3. W dyskusji na temat kształtu czternastej dyrektywy pojawiają się również innego rodzaju pytania: Czy dyrektywa ma być poświęcona tylko transgranicznemu przekształceniu spółki, czy może - przy okazji zapowiedzi sca-

${ }_{13}$ Teza 34 wyroku TS w sprawie C-378/10 (Vale).

${ }_{14}$ Teza 35 wyroku TS w sprawie C-378/10 (Vale).

15 „Should the transfer of a registered office be compulsory along with the transfer of the headquarters (main office)?" Dokument konsultacyjny (pytanie V.1). Polski przekład tego pytania nie jest precyzyjny.

${ }^{16}$ Feedback Statement, s. 13.

${ }_{17}$ Zob. http://ec.europa.eu/internal_market/consultations/2013/seat-transfer/contributions_ en.htm. „Nie dostrzegamy dostatecznego uzasadnienia dla przenoszenia siedziby statutowej, jeżeli nie towarzyszy temu przeniesienie głównego miejsca prowadzenia działalności lub głównego biura. Mogłoby to służyć głównie obchodzeniu prawa dotychczasowej siedziby i miejsca prowadzenia działalności. Opowiadamy się za jednolitością siedziby statutowej i głównego miejsca prowadzenie działalności oraz głównego biura".

${ }^{18}$ P7_TA(2012)0019. Załącznik - zalecenie nr 1 zd. 2. 
lenia (kodyfikacji) dyrektyw - przekształcenie ma być jednym z segmentów dyrektywy w sprawie (wszystkich) transgranicznych restrukturyzacji? Czy ma dotyczyć spółek kapitałowych, czy także osobowych? Czy przedmiotem dyrektywy ma być tylko przekształcenie spółki krajowej w jej zagraniczny odpowiednik (rechtsformkongruente statutenwechselnde Sitzverlegung), czy także w inną spółkę (rechtsforminkongruente statutenwechselnde Sitzverlegung)? Nie do końca jasne jest także, jak należy rozumieć siedzibę faktyczna (rzeczywista): Czy tak jak w pytaniu zadanym w czasie konsultacji - jako siedzibę organu zarządzającego (ang. headquarters, main office $\left.{ }^{19}\right)^{20}$, czyli miejsca, w którym podejmowane są bieżące decyzje dotyczące działalności spółki, czy może siedzibę głównego miejsca prowadzenia działalności gospodarczej (ang. principal place of business; niem. Hauptniederlassung)?

Natomiast nie jest rozważana - i nie stanowi postaci korzystania ze swobody przedsiębiorczości ${ }^{21}$ - możliwość przeniesienia siedziby statutowej spółki do innego państwa członkowskiego z zachowaniem jej dotychczasowego statusu prawnego. Obecnie nie rozważa się także, czy dyrektywa (niezależnie od regulacji transgranicznego przekształcenia) powinna regulować przeniesienie samej siedziby faktycznej ${ }^{22}$. Dyskusja toczy się więc „tylko” wokół pytania: Czy regulacja transgranicznego przekształcenia powinna umożliwiać przeniesienie samej siedziby statutowej, czy łącznie z przeniesieniem siedziby faktycznej (wymogiem prowadzenia działalności w państwie przyjmujaccym)? Nie jest ona łatwa, ponieważ dotyka głównych problemów międzynarodowego prawa spółek $^{23}$, a poza tym w jej tle widoczne są argumenty za lub przeciw większej integracji gospodarczej UE.

4. W dyskusji tej eksponowany jest m.in. watek dotyczacy podstawy prawnej wydania czternastej dyrektywy. Do stosowania środków harmonizacji prawa krajowego wymienionych w art. 288 TfUE (w tym dyrektyw) instytucje Unii muszą być bowiem w traktatach umocowane: „każda instytucja działa w granicach uprawnień przyznanych jej na mocy Traktatów, zgodnie z procedurami, na warunkach i w celach w nich określonych" (art. 13 ust. 2 zd. 1 $\left.\mathrm{TUE}^{24}\right)$. Naturalną traktatowa podstawą prawną dyrektywy w sprawie trans-

${ }^{19} \mathrm{~W}$ art. 54 ust. 1 TfUE mowa jest o central administration (niem. Hauptverwaltung).

20 Feedback Statement, s. 13.

21 W. Schön, op. cit., s. 356.

22 Można dodać, że wariant przeniesienia samej siedziby faktycznej spółki rozważany był w studium przygotowanym przez K.P.M.G European Business Centre. Studium to zawierało dwie propozycje dyrektywy: jedna, zgodnie z koncepcją kolizyjnej teorii założenia, regulowała przeniesienie siedziby faktycznej przy zachowaniu statusu prawnego państwa inkorporacji spółki. Druga - uwzględniając kolizyjną teorię siedziby - dotyczyła przeniesienia siedziby statutowej i faktycznej. Por. Studie über die Verlegung des Sitzes einer Gesellschaft von einem Mitgliedstaat in einen anderen, Luxemburg 1993 - K.P.M.G European Business Centre, Bruksela.

${ }^{23}$ Które samo w sobie niesie wiele pytań, a wiele tez funkcjonuje obok roboczych hipotez. W. Klyta, Podmioty międzynarodowych transakcji handlowych, w: System prawa handlowego, red. S. Włodyka, t. 9: Międzynarodowe prawo handlowe, red. W. Popiołek, Warszawa 2013, s. $108-110$.

${ }^{24}$ Traktat o Unii Europejskiej z 7 lutego 1992 r. (Dz. Urz. UE 83 z 30 marca 2010 r., s. 13). 
granicznego przekształcenia wydaje się art. 50 ust. 2 lit. g TfUE, ponieważ na podstawie tego przepisu (i jego dotychczasowego odpowiednika: art. 44 ust. 2 lit. g TWE ${ }^{25}$ ) zostały wydane wszystkie dyrektywy dotyczące prawa spółek, w tym dyrektywa w sprawie transgranicznego łączenia się spółek ${ }^{26}$. Również Parlament Europejski w rezolucji z 2 lutego 2012 r. ${ }^{27}$ postuluje szybkie przedłożenie na podstawie art. 50 ust. 1 i art. 50 ust. 2 lit. g TfUE wniosku dotyczącego dyrektywy w sprawie transgranicznego przeniesienia siedziby spółki w oparciu o zalecenia przedstawione w załączniku do tej rezolucji (w zaleceniu nr 1 zd. 2 tego załącznika czytamy, że: „Jej zakres powinien obejmować odpowiednie rozwiązanie kwestii oddzielenia siedziby statutowej spółki od jej siedziby administracyjnej").

Możliwość wydania dyrektywy regulującej transgraniczne przekształcenie bez przeniesienia siedziby faktycznej kwestionowana jest głównie z dwóch powodów:

Po pierwsze - ponieważ uchwalenie dyrektywy na podstawie art. 50 ust. 2 lit. g TfUE ma służyć urzeczywistnieniu swobody przedsiębiorczości (art. 50 ust. 1 TfUE) ${ }^{28}$, a - zgodnie z przyjętą przez Trybunał wykładnią art. 49 TfUE samo przekształcenie, bez elementu realnego, nie jest postacia korzystania $\mathrm{z}$ tej swobody ${ }^{29}$. Innymi słowy, wykładnia swobody przedsiębiorczości przez Trybunał wywiera bezpośredni wpływ na kompetencję unijnego ustawodawcy do wydania dyrektywy niezgodnej z tą wykładnią ${ }^{30}$.

Po drugie - ponieważ traktatowa zasada subsydiarności (art. 5 ust. 3 TUE) wyklucza ingerencję ustawodawcy unijnego w prawo kolizyjne państw członkowskich.

25 Traktat ustanawiający Wspólnotę Europejską z 25 marca 1957 r. (Dz. Urz. WE C 321E z 29 grudnia 2006 r., s. 1).

${ }^{26}$ Jako formalna podstawa wydania dyrektywy został wskazany art. 50 TfUE.

27 P7_TA(2012)0019.29.12.2006, s. 1.

28 Art. 50 TfUE jako całość stanowi integralną część tytułu IV rozdziału 2 TfUE regulującego swobodę przedsiębiorczości. O. Mörsdorf, The Legal Mobility of Companies within the European Union trough Cross-Border Conversion, „Common Market Law Review” 2012, z. 2, s. 662. Należy dodać, że podstawa prawna uchwalenia dyrektywy kwestionowana była również w związku z dyskusją nad projektem z 1997 r. P. O. Mülbert, K. U. Schmolke, Die Reichweite der Niederlassungsfreiheit von Gesellschaften-Anwendungsgrenzen der Art. 43 ff. EGV bei kollisions- und sachrechtlichen Niederlassungshindernissen, „Zeitschrift für Vergleichende Rechtswissenschaft. Archiv für Internationales Wirtschaftsrecht” 2001, s. 272-274.

29 „Since such an operation does not fall within the scope of freedom of establishment, Article 50(1) TFEU does not constitute a legal basis for legislation, with the result that such a competence must be derived from other Treaty provisions". O. Mörsdorf, The Legal Mobility of Companies within the European Union, s. 661. Podobnie P. Kindler, Der reale Niederlassungsbegriff nach dem VALE-Urteil des EuGH, „Europäische Zeitschrift für Wirtschaftsrecht” 2012, z. 23, s. 892; Anmerkung von Oliver Mörsdorf und Christian Jopen, „Zeitschrift für Wirtschaftsrecht” 2012, z. 29, s. 1399. T. Biermeyer, Shaping the Space of Cross-Border Conversion in EU. Between Right and Autonomy: VALE, „Common Market Law Review” 2013, z. 2, s. 588; L. Böttscher, J. Kraft, Grenzüberschreitender Formwechsel und tatsächliche Sitzverlegung - Die Entscheidung VALE des EuGH, „Neue Juristische Wochenschrift” 2012, z. 37, s. 2703; G. H. Roth, Das Ende der Briefkastengründung? - Vale contra Centros, „Zeitschrift für Wirtschaftsrecht” 2012, z. 36, s. 1744-1745.

${ }^{30}$ P. Kindler, op. cit., s. 892. 


\section{WPŁYW WYKŁADNI TRYBUNAŁU ART. 49 TFUE NA KSZTAET CZTERNASTEJ DYREKTYWY}

\section{Uwagi wstępne}

1.1. Oczywiście, że ustawodawca unijny może działać tylko w ramach przyznanej mu kompetencji (art. 5 ust. 1 TUE), a Trybunał Sprawiedliwości kontroluje legalność unijnych aktów prawodawczych (art. 263 TfUE, wcześniej art. 230 TWE). Prawdą jest również to, że wyroki Trybunału są wiążące zarówno dla organów państw członkowskich, jak i organów Unii Europejskiej ${ }^{31}$.

1.2. Przy eksponowaniu ryzyka związanego $\mathrm{z}$ uchwaleniem czternastej dyrektywy - umożliwiającej rozdzielenie siedzib - wskazywany jest wyrok w sprawie C-376/98 (Republika Federalna Niemiec przeciwko Parlamentowi Europejskiemu i Radzie) ${ }^{32}$, w którym Trybunał stwierdził nieważność dyrektywy $\mathrm{nr} 98 / 43 / \mathrm{WE}^{33}$. Dyrektywa ta została wydana na podstawie art. 57 ust. 2 TWE (po zmianie art. 47 ust. 2 TWE, obecnie art. 53 ust. 2 TfUE), art. 66 TWE (po zmianie art. 53 TWE, obecnie art. 63 TfUE) oraz art. 100a TWE (po zmianie art. 95 TWE, obecnie art. 114 TfUE). Na podstawie art. 100a TWE (obecnie art. 114 TfUE) Parlament Europejski i Rada przyjmuja środki harmonizujące przepisy krajowe, „które mają na celu ustanowienie i funkcjonowanie rynku wewnętrznego". Dokonując wykładni tego przepisu, Trybunał podkreślił: po pierwsze - przepis ten nie udziela prawodawcy wspólnotowemu ogólnej kompetencji do regulowania rynku wewnętrznego (byłoby to bowiem sprzeczne z zasadą wynikająca obecnie z art. 5 ust. 2 TfUE); po drugie - akt przyjęty na podstawie art. 100a musi mieć na celu poprawę warunków ustanowienia i funkcjonowania rynku wewnętrznego; zastosowanie tej podstawy jest możliwe w celu zapobieżenia powstaniu przyszłych przeszkód w handlu: powstanie takich szkód musi być prawdopodobne, a dany akt musi mieć na celu zapobieżenie $\mathrm{im}^{34}$. Zdaniem Trybunału wprowadzenie zakazu reklamy i sponsorowania wyrobów tytoniowych nie uzasadnia ani konieczność usunięcia przeszkód w swobodnym przepływie nośników reklamy i swobodnym świadczeniu usług, ani konieczność usunięcia istotnych zakłóceń konkurencji w „sektorze reklamy” lub na rynku wyrobów tytoniowych ${ }^{35}$.

${ }^{31}$ S. A. E. Martens, Methodenlehre des Unionsrecht, Tübingen 2013, s. 303-304. Ch. Teichmann, Überprüfung von Sekundärrecht am Maßstab der Grundfreiheiten, w: P.-Ch. Müller-Graff, S. Schmahl, V. Skouris (red.), Festschrift für Dieter H. Scheuing, Baden-Baden 2011, s. 745.

${ }^{32}$ Wyrok TS z 5 października 2000 r. w sprawie C-376/98 (Republika Federalna Niemiec przeciwko Parlamentowi Europejskiemu i Radzie).

${ }^{33}$ Dyrektywa nr 98/43/WE Parlamentu Europejskiego i Rady z 6 lipca 1998 w sprawie zbliżenia przepisów ustawowych, wykonawczych i administracyjnych państw członkowskich odnoszących się do reklamy i sponsorowania wyrobów tytoniowych (Dz. Urz. L 213, s. 9).

${ }^{34}$ Tezy 83-86 wyroku TS z 5 października 2000 r. w sprawie C-376/98 (Republika Federalna Niemiec przeciwko Parlamentowi Europejskiemu i Radzie). W tezie 87 Trybunał dodał, że powyższe rozważania odnoszą się także do wykładni art. 57 ust. $2 \mathrm{w}$ związku z art. 66 TWE.

${ }_{35}$ Tezy 105 i 114 wyroku TS z 5 października 2000 r. w sprawie C-376/98 (Republika Federalna Niemiec przeciwko Parlamentowi Europejskiemu i Radzie). Wykaz publikacji, w których 
W wyroku tym dokonana została wykładnia art. 100a TWE (obecnie art. 114 TfUE) jako podstawy do wydania dyrektywy nr 98/43/WE dotyczącej reklamy i sponsorowania produktów tytoniowych. Podstawa ta okazała się niewłaściwa. Orzekajac, czy art. 100a TWE (obecnie 114 TfUE) stanowi odpowiednią podstawę prawna, Trybunał musiał „zbadać, czy akt, którego ważność stanowi przedmiot sporu, realizuje rzeczywiście cele wskazane przez prawodawcę wspólnotowego" ${ }^{36}$.

Gdyby natomiast czternasta dyrektywa została wydana na podstawie art. 50 ust. 2 lit. g TfUE, to orzekając o jej nieważności, Trybunał musiałby wykazać, że umożliwienie spółkom przenoszenia siedziby statutowej (przekształcenia) spółki bez przeniesienia siedziby faktycznej nie stanowi urzeczywistnienia swobody przedsiębiorczości w rozumieniu art. 50 ust. 1 TfUE. Takie orzeczenie wydaje się mało prawdopodobne:

Po pierwsze - do kontroli unijnego prawa wtórnego z perspektywy podstawowych swobód Trybunał podchodzi z dystansem ${ }^{37}$, a przedmiotem kontroli jest ewentualne ograniczenie swobody $^{38}$. Zarazem jednak punktem wyjścia uzasadniajacym kontrolne samoograniczenie Trybunału (ang. judicial self restraint, niem. reduzierte Kontrolldichte) jest założenie o zgodności unijnych dyrektyw prawa spółek ze swobodą przedsiębiorczości; w konsekwencji swobody przedsiębiorczości nie naruszaja przepisy krajowe, które sa zgodne z (jedenasta) dyrektywą ${ }^{39}$. Stosowanie przez Trybunał „dwojakiej miary” w porównaniu ze związaniem wyrokiem TS państw członkowskich - znajduje usprawiedliwienie w tym, że traktatowe swobody (także swoboda przedsiębiorczości) oraz traktatowe umocowania do harmonizacji przepisów krajowych (w tym zawarte w art. 50 TfUE) wzajemnie się uzupełniaja, by wspólnie służyć funkcjonowaniu rynku wewnętrznego ${ }^{40}$. W każdym razie czternasta dyrektywa uchwalona w imię zmniejszenia ograniczeń swobody przedsiębiorczości a więc w celu urzeczywistnienia tej swobody (art. 50 ust. 1 TfUE) - może pójść

wyrażane są różne stanowiska co do wpływu tego wyroku na kompetencje ustawodawcy unijnego: M. Möstl, Grenzen der Rechtsangleichung im europäischen Binnenmarkt. Kompetenzielle, grundfreiheitliche und grundrechtliche Schranken des Gemeinschaftsgesetzgebers, „Europarecht” 2002, s. 319, przyp. 5.

${ }^{36}$ Podobnie w wyroku w sprawie z 13 lipca 1995 r. w sprawie C-350/92 (Hiszpania przeciwko Radzie), tezy 25-41 oraz wyrok z 13 maja 1997 r. w sprawie C-233/94 (Republika Federalna Niemiec przeciwko Parlamentowi Europejskiemu i Radzie), tezy 10-21.

${ }^{37}$ T. Drygala, Europäische Niederlassungsfreiheit vor der Rolle rückwärts?, „Europäische Zeitschrift für Wirtschaftsrecht” 2013, z. 15, s. 571; Ch. Teichmann, Gesellschaftsrecht im System der Europäischen Niederlassungsfreiheit, „Zeitschrift für Unternehmens- und Gesellschaftsrecht” 2011, z. 6, s. 656-657, gdzie odwołuje się m.in. do tezy 56 wyroku z 13 maja 1997 r. w sprawie C-233/94 (Republika Federalna Niemiec przeciwko Parlamentowi Europejskiemu i Radzie): „In such a situation the Court cannot substitute its own assessment for that of the Community legislature [wyróż. - J.N.]. It could, at most, find fault with its legislative choice only if it appeared manifestly incorrect or if the resultant disadvantages for certain economic operators were wholly disproportionate to the advantages otherwise offered".

${ }^{38}$ Teza 21 wyroku TS z 9 sierpnia 1994 r. w sprawie C-51/93 (Meyhui). Zwraca na to uwage

Ch. Teichmann, Überprüfung..., s. 755 .

${ }^{39}$ Teza 58 wyroku TS z 30 września 2003 r. w sprawie C-167/01 (Inspire Art). Ch. Teichmann, Überprüfung..., s. 748.

${ }^{40}$ Ch. Teichmann, Gesellschaftsrecht im System..., s. 656. 
inną droga, niż wynika to z wyroków Trybunału rozstrzygających konkretne sprawy, i np. powiązać wymóg przeniesienie siedziby faktycznej z prawem państwa przyjmującego.

Po drugie - zakwestionowanie ważności czternastej dyrektywy z omawianego powodu musiałoby się łączyć z zakwestionowaniem ważności dyrektywy w sprawie transgranicznego łączenia się spółek, która wydana została na podstawie art. 50 TfUE i nie przewiduje - jako przesłanki transgranicznego połaczenia - prowadzenia przez spółkę przejmującą (nowo utworzona) działalności gospodarczej w państwie jej inkorporacji. Utrwalona praktyka jest zreszta uzyskanie zbliżonego do transgranicznego przekształcenia efektu przez tworzenie zagranicznej spółki tylko po to, by wystapiła w roli spółki przejmującej: zamiast przeniesienia siedziby statutowej z państwa A do B, można w państwie B założyć spółkę córkę, która następnie jako spółka przejmująca połączy się ze spółką matka. Państwo B musi wpisać do rejestru spółkę przejmująca nawet wówczas, gdyby była „spółką pozorną”, i nie może powołać się na wymóg „prowadzenia działalności” przewidziany w wyroku Vale ${ }^{41}$.

Po trzecie - wymóg faktycznego wykonywania działalności gospodarczej w państwie przyjmujacym (ang. the pursuit of genuine economic activity concerned in that State; niem. die Ausübung einer wirklichen wirtschaftlichen Tätigkeit) jest (a) tyle wysoce nieprecyzyjny, co archaiczny; a poza tym (b) w tym samym wyroku (Vale) Trybunał potwierdza autonomię państwa członkowskiego do określania podmiotowego zakresu swobody przedsiębiorczości (art. 54 TfUE).

\section{Wykonywanie działalności gospodarczej w państwie przyjmującym?}

\subsection{Nieprecyzyjne kryterium}

Zgodnie z tezą wyroku w sprawie Vale kwalifikacja określonej ekspansji gospodarczej do innego państwa członkowskiego - także przybierająca postać transgranicznego przekształcenia - wymaga utworzenia (tu: reinkorporacji) danej spółki w tym państwie i faktycznego wykonywania na jego terytorium działalności gospodarczej przez stały zakład ${ }^{42}$.

Ale jak należy rozumieć wymóg prowadzenia działalności gospodarczej w państwie przyjmujacym? Trafne pytania dotyczące tej problematyki stawia Tim Drygala: Jaka intensywność prowadzenia działalności gospodarczej jest wymagana? W jakim momencie „stały zakład” powinien funkcjonować: chyba nie tylko przed rejestracja nowej siedziby statutowej spółki (np. jako wyposażenie oddziału)? Czy wystarczy oświadczenie o zamiarze prowadzenia działalności gospodarczej? A jakie wynikną konsekwencje, jeżeli - mimo deklarowanego zamiaru - działalność gospodarcza w państwie przyjmującym nie będzie prowadzona? Kto to miałby sprawdzać? A w jaki sposób sprawdzać wymóg prowadzenia działalności gospodarczej w państwie przyjmującym: czy

${ }^{41}$ T. Drygala, op. cit., s. 571-572: „Das Sekundärrecht ist hier schon über die Auslegung des Primärrecht durch den EuGH hinweggegangen; dessen Rechtsprechung ist insoweit nicht mehr zeitgemäßt" (s. 572).

${ }^{42}$ Teza 34 wyroku TS z 12 lipca 2012 r. w sprawie C-378/10 (Vale). 
od strony formalnej, badając wyposażenie (co łatwo obejść), czy materialnej, badając proporcje między działalnością gospodarczą w tym kraju a zagraniczna (co prowadzi do niepewności prawnej)? I wreszcie: czy w dobie Internetu w ogóle zasadny jest wymóg posiadania stałego zakładu, jeżeli celem transgranicznego przekształcenia jest przybranie formy prawnej spółki tego państwa, w którym znajduje się jej klientela? ${ }^{43}$

Można dodać, że wymóg posiadania „stałego zakładu” nie przystaje do rozumienia siedziby rzeczywistej jako miejsca, w którym podejmowane sa główne decyzje władz spółki (siedziba zarządu). Prowadzenie działalności gospodarczej przez przekształconą spółkę może przecież polegać na zarządzaniu działalnościa gospodarczą spółki wykonywaną de facto w innym państwie członkowskim (korzystając ze swobody świadczenia usług bądź prowadząc działalność przez oddział). Nawiązując do judykatu Vale, można przyjać, że tak jak Vale Costruzioni S.r.l. mogłaby z Włoch zarządzać działalnością na Węgrzech, tak i przekształcona węgierska spółka Vale Építési kft mogłaby nadal wykonywać działalność gospodarczą na terytorium Włoch.

Poza tym za przyznaniem spółkom krajowym możliwości przekształcania się w spółkę zagraniczną z zachowaniem w państwie emigracji ich dotychczasowej siedziby faktycznej ${ }^{44}$ przemawia wtórne prawo unijne, które nie wyklucza możliwości przekształcenia spółki krajowej w spółkę zagraniczną z pozostawieniem „głównego ośrodka podstawowej działalności” w dotychczasowym państwie ${ }^{45}$.

\subsection{Element definicji czy postać ograniczania swobody przedsiębiorczości?}

W wyroku w sprawie Vale Trybunał expressis verbis odwołał się do tezy wyroku w sprawie Cadbury Schweppes ${ }^{46}$. Zdaniem TS swoboda przedsiębiorczości stoi na przeszkodzie brytyjskim przepisom podatkowym, na mocy których dochody spółek zależnych (spółek córek) - inkorporowanych w państwie o niższym poziomie opodatkowania (w tej sprawie: w Irlandii, w Międzynarodowym Centrum Usług Finansowych w Dublinie) - doliczane sa do dochodu spółki dominującej (córki-matki). Zdaniem Trybunału spółka, której ustawodawca krajowy utrudnia zakładanie spółki córki w celu skorzystania z niższego opodatkowania w innym państwie członkowskim, może powoływać się na traktatowy zakaz ograniczania swobody przedsiębiorczości (art. 43 TWE).

43 T. Drygala, op. cit., s. 570-571.

${ }^{44}$ C. Behme, Der grenzüberschreitende Formwechsel von Gesellschaften nach Cartesio und Vale, „Neue Zeitschrift für Gesellschaftsrecht” 2012, nr 24, s. 939 i literatura w przyp. 31.

${ }^{45}$ Wskazanie takiego miejsca pozwala „tylko” na obalenie domniemania wynikającego z art. 3 ust. 1 zd. 2 rozporządzenia nr 1346/2000, zgodnie z którym ośrodek ten znajduje się w miejscu siedziby statutowej spółki. Zgodnie z tezą 13 preambuły tego rozporządzenia - „główny ośrodek podstawowej działalności powinien oznaczać miejsce, w którym dłużnik zazwyczaj zarządza swoją działalnością i jako takie jest rozpoznawalne przez osoby trzecie”. Zarządzanie swoją działalnością po przeniesieniu siedziby do innego państwa członkowskiego może polegać także na prowadzeniu czynności likwidacyjnych - teza 71 opinii rzecznika generalnego J. Kokott z 10 marca 2011 r. w sprawie C-396/09 (Interedil Srl, w likwidacji).

${ }^{46}$ Wyrok TS z 12 września 2006 r. w sprawie C-196/04 (Cadbury Schweppes). 
Powoływanie się na zakaz ograniczania swobody przedsiębiorczości jest natomiast - zdaniem Trybunału - wykluczone, jeżeli korzystanie ze swobody ma znamiona nadużycia lub oszustwa ${ }^{47}$. Chodzi w szczególności o zapobieganie tworzeniu sztucznych struktur, które nie posiadaja dostrzegalnych (obiektywnych) atrybutów swobody przedsiębiorczości. Jeżeli więc istnieją podstawy do wniosku, że taka jednostka odpowiada fikcyjnemu zakładowi, niewykonującemu faktycznie żadnej działalności gospodarczej na terytorium przyjmujacego państwa członkowskiego, to jej założenie „należy uważać za posiadające cechy czysto sztucznej struktury. Miałoby to miejsce w szczególności w przypadku spółki zależnej o charakterze »spółki adresowej« lub "firmy-krzak«"48.

Dla niniejszych rozważań istotne jest również to, że w wyroku Cadbury Schweppes TS z jednej strony uznał co prawda, że nie stanowi korzystania ze swobody przedsiębiorczości utworzenie za granicą spółki będącej konstrukcją sztuczną (nieprowadząca działalności gospodarczej); z drugiej strony natomiast przyją, że krajowe przepisy ograniczające tego typu praktykę powinny spełniać warunek proporcjonalności ${ }^{49}$. Wymóg prowadzenia działalności gospodarczej TS traktuje zatem jako przejaw ograniczenia swobody przedsiębiorczości i ${ }^{50}$.

O tym, że wymóg prowadzenia działalności spółki w państwie przyjmujacym może nie być traktowany jako element definicyjny swobody przedsiębiorczości, świadczy jeszcze wyraźniej sformułowanie tezy 34 Trybunału w wyroku Vale. Zarówno w tytule tej części uzasadnienia wyroku, jak i w samej tezie 34 mowa jest o wymogu prowadzenia działalności gospodarczej jako o wymogu, który ogranicza swobodę przedsiębiorczości (ang.: „As regards the existence of a restriction on the freedom of establishment [...]”; niem.: „In Bezug auf das Vorliegen einer Beschränkung der Niederlassungsfreiheit [...]"). Okoliczność ta wskazywana jest jako argument przemawiający za tym, by wymóg prowadzenia działalności nie traktować jako konstytutywną cechę swobody przedsiębiorczości ${ }^{51}$.

\subsection{Autonomia państw członkowskich}

\subsubsection{Spółka jako twór państwa inkorporacji i państwa reinkorporacji}

Zgodnie z art. 54 akapit 1 TfUE ze swobody przedsiębiorczości może korzystać spółka założona „zgodnie z ustawodawstwem państwa członkowskiego”. Krajowe prawo spółek stanowiące podstawę inkorporacji spółki ma charakter autonomiczny.

Utworzona spółka krajowa jest tworem prawa państwa inkorporacji i tylko ono przesądza o przesłankach jej powstania i jej istnienia. Teza ta -

${ }_{47}$ Teza 35 wyrok TS w sprawie C-196/04 (Cadbury Schweppes).

${ }_{48}$ Teza 68 wyrok TS w sprawie C-196/04 (Cadbury Schweppes).

${ }^{49}$ Teza 57 wyrok TS w sprawie C-196/04 (Cadbury Schweppes).

${ }^{50}$ W. Bayer, J. Schmidt, Das Vale-Urteil des EuGH: Die entgültige Bestätigung der Niederlassungsfreiheit als “Formwechselfreiheit”, „Zeitschrift für Wirtschaft” 2012, z. 31, s. 1486.

${ }^{51}$ Ibidem, s. 1486; T. Drygala, op. cit., s. 570. 
sformułowana wcześniej w wyrokach w sprawach Daily Mail $^{52}$, Cartesio ${ }^{53}$ i National Grid Indus ${ }^{54}$ - została uwzględniona w wyroku w sprawie Vale ${ }^{55}$.

Z kolei o przesłankach istnienia i funkcjonowania spółki „przekształconej” przesądza prawo tego państwa, w którym została ona reinkorporowana. Innymi słowy: tak jak prawo państwa emigracji - z uwagi na wymóg łączności siedziby statutowej i faktycznej - może uniemożliwić funkcjonowanie spółki w innym państwie członkowskim bez zmiany dotychczasowego statutu personalnego (Cartesio, National Grid Indus), tak prawo państwa przyjmującego (imigracji) przesądza o tym, czy dla skutecznej „reinkorporacji” - dla której niezbędna jest oczywiście zmiana (,przeniesienie”) siedziby statutowej konieczna jest w tym państwie lokalizacja siedziby faktycznej spółki (Vale).

\subsubsection{Transgraniczna mobilność spółek w orzecznictwie TS}

O oddziaływaniu orzecznictwa Trybunału Sprawiedliwości na wtórne prawo UE należy mówić nie przez pryzmat jednego wyroku wydanego w konkretnej sprawie, lecz z perspektywy całego dorobku orzeczniczego Trybunału. Zarysowując wykształcone w orzecznictwie TS możliwości transgranicznej mobilności spółek, należy rozróżnić następujące warianty: po pierwsze (a) przeniesienie „tylko” faktycznej siedziby (centrum) spółki oraz (b) transgraniczne przekształcenie, które wymaga zmiany (,przeniesienia”) siedziby statutowej; po drugie - (c) perspektywę państwa, z którego spółka emigruje, oraz (d) państwa, do którego spółka się przenosi ${ }^{56}$.

Zdaniem Trybunału swoboda przedsiębiorczości nie ogranicza państwu członkowskiemu podejmowania środków uniemożliwiających spółce przenoszenie swej siedziby faktycznej (centrum działalności) do innego państwa członkowskiego, jeżeli spółka ta nadal pozostaje spółką państwa, z którego emigruje (Cartesio i National Grid Indus). Są takie państwa członkowskie, które umożliwiają swoim spółkom tego rodzaju emigrację (np. Holandia National Grid Indus), oraz takie, które na to swoim spółkom nie zezwalaja, wiążąc je wymogiem krajowej lokalizacji siedziby rzeczywistej (np. Węgry Cartesio). Państwo członkowskie nie może natomiast uniemożliwić spółce kontynuowania działalności gospodarczej połączonego ze zmianą dotychczasowego statutu personalnego. Również sytuacja prawna spółki przenoszącej swą siedzibę faktyczną z innego państwa członkowskiego zależy od tego, czy państwo pochodzenia umożliwia tego typu emigrację, czy też nie. W pierwszym wypadku przeniesienie siedziby nie powinno prowadzić do zmiany jej dotychczasowego statusu prawnego: państwo członkowskie, do którego spółka przeniosła swą faktyczną siedzibę, powinno uwzględniać („uszanować”) jej zdolność prawną i sądowa, którą uzyskała zgodnie z prawem państwa swej inkorporacji (założenia). Państwo członkowskie nie może więc zmuszać spółki

${ }^{52}$ Wyrok TS z 27 września 1988 r. w sprawie C-81/87 (Daily Mail).

${ }^{53}$ Wyrok TS z 16 grudnia 2008 r. w sprawie C-210/06 (Cartesio)

${ }^{54}$ Wyrok TS z 20 listopada 2011 r. w sprawie C-371/10 (National Grid Indus).

${ }_{55}$ Teza 29 wyroku TS w sprawie C-378/10 (Vale); teza 110 wyroku TS w sprawie C-210/06 (Cartesio); teza 27 wyroku TS w sprawie C-371/10 (National Grid Indus).

${ }^{56}$ Szerzej na ten temat z perspektywy prawa unijnego i niemieckiego: V. Verse, Niederlassungsfreiheit und grenzüberschreitende Sitzverlegung - Zwischenbilanz nach "National Grid Indus” und "Vale”, „Zeitschrift für Europäisches Privatrecht” 2013, z. 3, s. 458 i n. 
zagranicznej do „asymilacji”, traktując ją jako spółkę swego prawa (wyrok C-208/00, Überseering ${ }^{57}$ ). Natomiast inny skutek spowoduje przeniesienie siedziby faktycznej z państwa, którego prawo kolizyjne wymaga łączności siedziby faktycznej ze statutowa, a zgodnie z regułami prawa materialnego rozszczepienie tych siedzib w drodze przeniesienia siedziby faktycznej za granicę jest przyczyną rozwiązania spółki i prowadzi do wykreślenia jej z krajowego rejestru. Fakt utraty statusu spółki prawa obcego powinien być honorowany również w państwie, do którego spółka przenosi siedzibę faktyczna, niezależnie od treści łącznika prawa kolizyjnego tego państwa.

Państwo członkowskie może więc uniemożliwić spółce krajowej prowadzenia w sposób trwały działalności za granicą w dotychczasowej postaci prawnej. Nie może jednak tego zrobić, jeżeli spółka zmienia lokalizację działalności i zarazem zmienia swój dotychczasowy status prawny, stając się spółką tego państwa, do którego emigruje. Sąd rejestrowy musi więc wykreślić (bez przeprowadzania likwidacji) spółkę krajową przekształcającą się w spółkę zagraniczna. Z kolei sąd rejestrowy w państwie przyjmujacym nie może - bez narażenia się na zarzut dyskryminacji - odmówić wpisu do rejestru przedsiębiorców zagranicznej spółki przekształconej w spółkę krajową zgodnie z wymogami przewidzianymi dla przekształceń spółek krajowych. Przesłanki reinkorporacji (wpisu) określa prawo państwa, w którym spółka (jako przekształcona) podlega rejestracji. Taką przesłanką może być (choć nie musi) lokalizacja siedziby faktycznej w państwie, do którego spółka „przeniosła” swą siedzibę statutowa. Jeżeli państwo członkowskie tego nie wymaga, transgraniczne przekształcenie może ograniczyć się do zmiany siedziby statutowej spółki ${ }^{58}$.

\subsubsection{Wniosek}

Artykuł 50 ust. 2 lit. g TfUE może stanowić podstawę do uchwalenia dyrektywy umożliwiającej przekształcenie się spółki w spółkę zagraniczną bez konieczności przenoszenia siedziby faktycznej. Zdaniem Trybunału Sprawiedliwości decyzja w tej kwestii leży w gestii państwa reinkorporacji spółki. Taka też jest rekomendacja Grupy Refleksyjnej ${ }^{59}$.

\section{INGERENCJA W PRAWO KOLIZYJNE PAŃSTW CZŁONKOWSKICH}

1. Stworzeniu w dyrektywie możliwości transgranicznego przekształcenia bez konieczności przeniesienia siedziby faktycznej na przeszkodzie stoi obawa przed ingerencją w krajowe prawo kolizyjne. Expressis verbis zostało to wyra-

${ }^{57}$ Wyrok TS z 5 listopada 2002 r. w sprawie C-208/00 (Überseering).

${ }^{58}$ W. Bayer, J. Schmidt, Das Vale-Urteil des EuGH..., s. 1486; Ch. Teichmann, Der Grenzüberschreitende Formwechsel ist spruchreif: das Urteil des EuGH in der Rs. Vale, „Der Betreib” 2012, z. 37, s. 2088; J. Napierała, Przeksztatcenie spótki zagranicznej w spótkę krajowa w świetle wyroku Trybunatu Sprawiedliwości Unii Europejskiej w sprawie Vale, „Ruch Prawniczy, Ekonomiczny i Socjologiczny" 2013, z. 1, s. 14.

${ }^{59}$ Response to the European Commission's, s. 318-319. 
żone w uzasadnieniu projektu czternastej dyrektywy z 22 kwietnia 1997 r. ${ }^{60}$ : Zdaniem Komisji taka harmonizacja oznaczałaby opowiedzenie się za określonym łącznikiem prawa kolizyjnego, a to oznaczałoby ingerencję w prawo krajowe niezgodne z zasadą subsydiarności ${ }^{61}$; zamierzone działanie (umożliwienie spółce przeniesienie siedziby do innego państwa członkowskiego ze zmianą dotychczasowego statutu personalnego) można bowiem osiagnąć w sposób wystarczajacy przez harmonizację prawa materialnego regulujacego stosowna procedurę transgranicznego przekształcenia spółki. Materialne prawo spółek miałoby więc pełnić rolę „[po]mostu” między systemami krajowego prawa kolizyjnego ${ }^{62}$. Właśnie z obawy przed takim zarzutem w projekcie dyrektywy z 1997 r. decyzję w sprawie konieczności przeniesienia siedziby statutowej łaccznie z siedzibą faktyczną pozostawiono w gestii państwa przyjmujacego (przyznanie prawa odmowy wpisu przeniesienia siedziby do rejestru, jeżeli siedzibie statutowej nie towarzyszy siedziba faktyczna - art. 11 ust. 2 projektu z 1997 r.).

2. Projekt dyrektywy z 1997 r. nie narzucał więc państwom członkowskim regulacji przewidujacej „rozdzielenie siedzib”; pozostawiał to w gestii państwa przyjmujaccego. Mimo to spotkał się z zarzutem ingerencji w krajowe reguły prawa kolizyjnego.

Jako „ingerujący” w prawo kolizyjne państwa przyjmującego, kierującego się założeniami teorii siedziby, postrzegany był art. 3 projektu dyrektywy z 1997 r., w myśl którego statut personalny spółki zmienia się wraz ze wpisem do rejestru nowej siedziby. O tym, że spółka podlega prawu państwa przyjmującego, nie przesądza bowiem zmiana siedziby faktycznej, lecz wpis do rejestru nowej siedziby statutowej. Ergo - choćby tylko przez „jurydyczną sekundę”spółka mająca siedzibę faktyczną w państwie hołdującym „teorii siedziby (faktycznej)" podlegałaby prawu państwa inkorporacji ${ }^{63}$.

Z kolei zmiana statutu personalnego spółki bez konieczności jej rozwiązania i likwidacji stanowi ingerencję w prawo kolizyjne państwa emigracji spółki

${ }^{60}$ Vorentwurf für eine Vierzehnte Richtlinie des Europäischen Parlaments und des Rates über die Verlegung des Sitzes einer Gesellschaft in einen anderen Mitgliedstaat mit Wechsel des für die Gesellschaft maßgebenden Rechts. Dok XV/6002/97. Tekst w języku niemieckim: M. Luter, W. Bayer, J. Schmidt, Europäisches Unternehmens- und Kapitalmarktrecht, „Zeitschrift für Unternehmens- und Gesellschaftsrecht”, Sonderheft 1/1, Berlin-Boston 2012, s. 1122-1127.

61 „Das Gemeinschaftsrecht hätte damit spürbar in das bestehende Recht der Mitgliedstaaten eingegriffen”. Pkt V zd. 2 uzasadnienia projektu dyrektywy z 1997 r.

${ }^{62}$ „Die Richtlinie versteht sich als Brücke zwischen den verschiedenen Rechtssystemen der Mitgliedstaaten”. Pkt VII zd. 2 uzasadnienia projektu dyrektywy z 1997 r.

${ }^{63}$ J. Hoffmann, Neue Möglichkeiten zur identitätswahrenden Sitzverlegung in Europa? Der Richtlinienvorentwurf zur Verlegung des Gesellschaftssitzes innerhalb der UE, „Zeitschrift für Unternehmens- und Gesellschaftsrecht” 2000, z. 1, s. 53-54; P. O. Mülbert, K. U. Schmolke, Die Reichweite der Niederlassungsfreiheit von Gesellschaften - Anwendungsgrenzen der Art. 43 ff. EGV bei kollisions- und sachrechtlichen Niederlassungshindernissen, „Zeitschrift für Vergleichende Rechtswissenschaft. Archiv für Internationales Wirtschaftsrecht” 2001, s. 273: „Tritt aber der Statutenwechsel gemäß Art. 3 S. 2 trotz der Verwaltungssitzverlagerung erst mit Eintragung ins Gesellschaftsregister des Zuzugsstates ein, steht diese Regelungswirkung im eindeutigen Widerspruch zur Sitztheorie”. 
hołdującego kolizyjnej „teorii inkorporacji”64. Łącznik siedziby inkorporacji spółki ma bowiem charakter „stały”65 (,zamrożony”66) i dlatego ze swej natury nie sprzyja korzystaniu ze swobody przedsiębiorczości w drodze transgranicznego przekształcenia spółki.

3. Ustosunkowując się do tego typu zarzutu, można podkreślić, że normy prawa kolizyjnego sa przecież obecne w unijnym prawie spółek i nie tylko nie naruszają swobody przedsiębiorczości, lecz ją wspieraja. Można w tym miejscu pominąć dyskusję nad zasadnością kwalifikacji samego art. 49 TfUE (regulującego istotę swobody przedsiębiorczości) jako przepisu, z którego wynika (ukryta) norma kolizyjna hołdująca teorii inkorporacji ${ }^{67}$. Nie sposób jednak nie zauważyć, że tego typu zarzuty „,ingerencji” w prawo kolizyjne można by również postawić dyrektywie nr 2005/56/WE w sprawie transgranicznego łaczenia się spółek kapitałowych, która „ułatwia transgraniczne połączenia” (pkt 2 preambuły dyrektywy nr 2005/56/WE), uchwalona została w celu „umożliwienia funkcjonowania jednolitego rynku" (pkt 1 preambuły dyrektywy nr 2005/56/WE), a „przepisy prawa krajowego, do których odwołuje się dyrektywa, nie powinny wprowadzać ograniczeń swobody przedsiębiorczości” (pkt 3 preambuły dyrektywy nr 2005/56/WE).

Rolę przepisu „ingerującego” pełni w szczególności ${ }^{68}$ art. 4 ust. 1 lit. b zd. 1 dyrektywy nr 2005/56/WE. Jest to norma prawa kolizyjnego ${ }^{69}$ wskazująca jako właściwe krajowe prawo materialne ${ }^{70}$, która implementowana do prawa państwa członkowskiego ma pierwszeństwo przed krajowymi ogólnymi regułami kolizyjnymi. Także z perspektywy państwa spółki przejmowanej, w którym obowiązuje teoria siedziby, spółka przejmująca (nowo utworzona) będzie spółką prawa państwa jej nowej siedziby statutowej - nawet jeżeli „stały zakład" w tym (nowym) państwie nie będzie zlokalizowany.

${ }^{64}$ J. Hoffmann, op. cit., s. 55.

65 A. W. Wiśniewski, Statut personalny spółek kapitałowych i uznawanie spółek zagranicznych. Orzecznictwo Trybunału Wspólnot a reforma polskiego prawa prywatnego międzynarodowego, w: A. Łazowski, R. Ostrihansky (red.), Wspótczesne wyzwania europejskiej przestrzeni prawnej. Księga pamiatkowa dla uczczenia 70. urodzin Profesora Eugeniusza Piontka, Kraków 2005, s. 717; A. Opalski, Europejskie prawo spółek - zasady prawa europejskiego i ich wpływ na polskie prawo spółek, Warszawa 2010, s. 97; W. Klyta, op. cit., s. 128 i cytowana w przyp. 4 wcześniejsza praca tego autora.

${ }^{66} \mathrm{~K}$. Oplustil, Eqcznik siedziby spótki w nowym prawie prywatnym międzynarodowym. Uwagi na tle prawa europejskiego, „Kwartalnik Prawa Prywatnego” 2011, nr 3, s. 641.

67 Por. np. M.-P. Weller, B. Rentsch, op. cit., s. 533 i literatura wskazana tam w przyp. 63. Inspiracji do takiej kwalifikacji dostarcza wyrok w sprawie Überseering (tezy 80-81). Pogłębioną analizę tego problemu prezentuje A. W. Wiśniewski, Uznanie zagranicznej osoby prawnej w cieniu art. 17 nowego prawa międzynarodowego, w: J. Poczobut (red.), Współczesne wyzwania prawa prywatnego międzynarodowego, Warszawa 2013, s. 342

68 Pomijając w tym miejscu art. 11 ust. 1 dyrektywy. A. Opalski, op. cit., s. 443; M.-P. Weller, B. Rentsch, op. cit., s. 530 i n.

69 A. Opalski, op. cit., s. 443.

70 S. Wohlfarter, Die kollisionsrechtliche Behandlung der grenzüberschreitenden Verschmelzung einer deutschen Kapitalgesellschaft mit einer Kapitalgesellschaft aus einem Andersen EU/ EWR-Staat, Hamburg 2014, s. 22 i n. 
Tego typu ingerencja w krajowe prawo kolizyjne będzie również niezbędna przy planowanej regulacji transgranicznego podziału spółki. Przy transgranicznym przekształceniu akceptuje ją także Trybunał, umożliwiając spółkom (o ile państwo przyjmujace na to pozwala) na zmianę siedziby statutowej bez przenoszenia działalności gospodarczej. Takiej zmianie siedziby (transgranicznemu przekształceniu) państwo emigracji nie może się przeciwstawić ${ }^{71}$.

\section{PODSUMOWANIE}

1. Czternasta dyrektywa umożliwiająca transgraniczne przekształcenie bez przeniesienia siedziby faktycznej byłaby wyrazem kompromisu leżącego u podstaw dyrektywy w sprawie transgranicznego łączenia się spółek kapitałowych oraz wypracowanego w orzecznictwie Trybunału w sprawach dotyczących transgranicznego przenoszenia siedziby spółki.

2. Czternasta dyrektywa uchwalona na podstawie art. 50 ust. 2 lit. g TfUE będzie sprzyjać urzeczywistnianiu swobody przedsiębiorczości (art. 50 ust. 1 TfUE) oraz zapewnieniu należytego funkcjonowania rynku wewnętrznego (art. 26 ust. 1 TfUE), którego fundamentem jest unijne prawo spółek ${ }^{72}$. Potwierdza to także teza 18 wyroku TS w sprawie C-97/96 (Daihatsu), w której Trybunał przyjmuje szeroką wykładnię ówczesnego odpowiednika obecnego art. 50 ust. 2 lit. g TfUE (art. 54 ust. 3 lit. g TWE), a mianowicie $\mathrm{z}$ uwzględnieniem nie tylko celu tego przepisu, ale także celu art. 3 lit. h TWE (obecnie art. 4 ust. 2 lit. a TfUE i art. 26 ust. 1), jakim jest zapewnienie funkcjonowania rynku wewnętrznego.

3. Umożliwienie transgranicznego przekształcenia bez przeniesienia siedziby faktycznej powinna leżeć w gestii państwa przyjmującego. Nie należy tego traktować jako ingerencji w krajowe prawo kolizyjne sprzecznej z traktatową zasadą subsydiarności. Takie ryzyko mogłoby natomiast nieść przesądzenie w samej dyrektywie o możliwości transgranicznego przekształcenia bez

${ }^{71}$ W. Bayer, J. Schmidt, Das Vale-Urteil des EuGH..., s. 1486; W. Schön, op. cit., s. 359: „[...] Schutzwirkung des Binnenmarktes gegenüber nationaler Gesetzgebung von der Schutzwüdrigkeit des herbeiführten wirtschaftlichen Zustandes abhängen muss und nicht von einer Bewertung des zufgewählten rechtlichen Weges”. Inaczej np. W. H. Roth, Grenzüberschreitender Rechtsformwechsel nach VALE, w: Festschrift für Michael Hoffmann-Becking zum 70. Geburstag, München 2013, s. 994; P. Kindler, op. cit., s. 891.

${ }^{72}$ W komunikacie z 12 grudnia 2012 r. (Plan działania 2012) Komisja Europejska podkreśla, że kluczowym elementem rynku wewnętrznego jest europejskie prawo spółek: „ułatwia ono przedsiębiorstwom korzystanie ze swobody przedsiębiorczości, a jednocześnie zwiększa przejrzystość, podnosi pewność prawa i polepsza kontrolę ich działalności”, COM (2012), 740, s. 4. K. J. Hopt, The European Company Law Action Plan Revisited: An Introduction, ECGI Working Paper Series in Law, Working Paper $N^{\circ} .140 / 2010$, February 2010, s. 11: „Corporate mobility is the essence of the internal market. We should do everything to promote it for the sake of entrepreneurial freedom as well as for the health effects of competition". 
konieczności przeniesienia siedziby faktycznej; najlepszym miejscem do takiej „ingerencji” byłoby - oczekiwane - unijne rozporządzenie o prawie właściwym dla spółek ${ }^{73}$.

4. Umożliwienie spółce rozdzielenia siedziby statutowej i faktycznej powinno być połączone z uregulowaniem środków skutecznej ochrony wierzycieli, wspólników mniejszościowych i pracowników spółki. Wzorzec wyznacza funkcjonująca dyrektywa w sprawie transgranicznego łączenia się spółek, która nie wymaga ani przeniesienia „stałego zakładu” spółki przejmowanej, ani łączności siedziby statutowej z faktyczną spółki przejmującej (nowo utworzonej); propozycje w tej sprawie zawiera projekt dyrektywy z 1997 r. oraz załącznik do rezolucji Parlamentu Europejskiego ${ }^{74}$.

5. W wyroku w sprawie Cartesio TS podkreślił, że główną swoją tezę formułuje „w obecnym stanie prawa wspólnotowego"75 oraz że od czasu wyroków w sprawie Daily Mail i Überseering „prace w zakresie rozwiazań legislacyjnych lub umów międzynarodowych w dziedzinie prawa spółek, o których mowa odpowiednio w art. 44 ust. 2 lit. g WE [obecnie art. 55 ust. 2 lit. g TfUE] i art. $293 \mathrm{WE}$ [obecnie uchylony - uzup. J.N.], nie dotyczyły dotychczas rozbieżności w ustawodawstwach krajowych, na których istnienie zwracały uwage te wyroki, i w zwiazku z tym nie doprowadziły do ich wyeliminowania"76. Dobrym rozwiązaniem legislacyjnym eliminujacym problemy, przed którymi stawał Trybunał, byłoby wydanie czternastej dyrektywy w sprawie transgranicznego przeniesienia siedziby (przekształcenia) spółki w proponowanym wyżej kształcie.

prof. dr hab. Jacek Napierata

Uniwersytet im. Adama Mickiewicza w Poznaniu

jnapier@amu.edu.pl

\section{SOME REMARKS ON THE SHAPE OF THE PLANNED COMPANY LAW DIRECTIVE ON CROSS-BORDER TRANSFER OF THE REGISTERED OFFICE}

Summary

While the conviction of the need for a fourteenth company law directive is almost universal, the discussion is going on around the question whether this directive should enable cross-border transfer by way of a transfer of the registered office without the need of the actual transfer of

${ }^{73}$ Projekt takiego rozporządzenia znajduje się w: H. J. Sonnenberger (red.), Vorschläge und Berichte zur Reform des europäischen und deutschen internationalen Gesellschaftsrechts, Tübingen 2007 , s. 65 i n.

${ }^{74}$ P7_TA(2012)0019. Treść propozycji Parlamentu Europejskiego omawia M. Mataczyński, Transgraniczne przeniesienie siedziby statutowej polskiej spótki za granice, „Problemy Prawa Prywatnego Międzynarodowego", t. 13 (red. M. Pazdan), Katowice 2013.

${ }^{75}$ Teza 4 sentencji wyroku w sprawie Cartesio; por także tezy 109 i 124 tego wyroku. Teza ta nawiązuje do tezy 25 wyroku TS w sprawie C-81/87 (Daily Mail). Do tych też nawiązują z kolei późniejsze wyroki Trybunału: teza 26 wyroku w sprawie Indus, teza 28 w sprawie Vale.

${ }^{76}$ Teza 4 sentencji wyroku TS z 16 grudnia 2008 r. w sprawie C-210/06 (Cartesio). 
its premises. Such scenario is being challenged because of two reasons: (i) a directive adopted based on Article 50 clause 2 letter $\mathrm{g}$ of the TEU is to serve making the freedom of establishment a reality, but pursuant to the ECJ's construction of Article 49 of the TEU, a mere transformation, without the actual, real element, does not amount to taking advantage of this freedom, and (ii) the subsidiarity principle provided for in the treaty (Article 5 clause 3 of the TEU) excludes the possibility of the EU law intervention in a conflict laws of Member states.

The fourteenth directive enabling a cross-border transfer without the actual transfer of the registered office, provided the law of the host state permitted, would be a manifestation of a reasonable compromise underlying the directive on cross-border mergers of companies that has been achieved in the course of the ECJ's judgments delivered in matters concerning a cross-border transfer of a registered office. 
Copyright of Journal of Law, Economics and Sociology is the property of Faculty of Law and Administration of Adam Mickiewicz University in Poznan and its content may not be copied or emailed to multiple sites or posted to a listserv without the copyright holder's express written permission. However, users may print, download, or email articles for individual use.

Właścicielem praw autorskich do „Ruchu Prawniczego, Ekonomicznego i Socjologicznego” jest Wydział Prawa i Administracji Uniwersytetu im. Adama Mickiewicza w Poznaniu. Zawartość czasopisma nie może być kopiowana, przesyłana do innych stron internetowych bądź zamieszczana na blogach bez pisemnej zgody wydawcy. Niemniej artykuły można drukować, kopiować lub przesyłać w formie elektronicznej na własny użytek. 